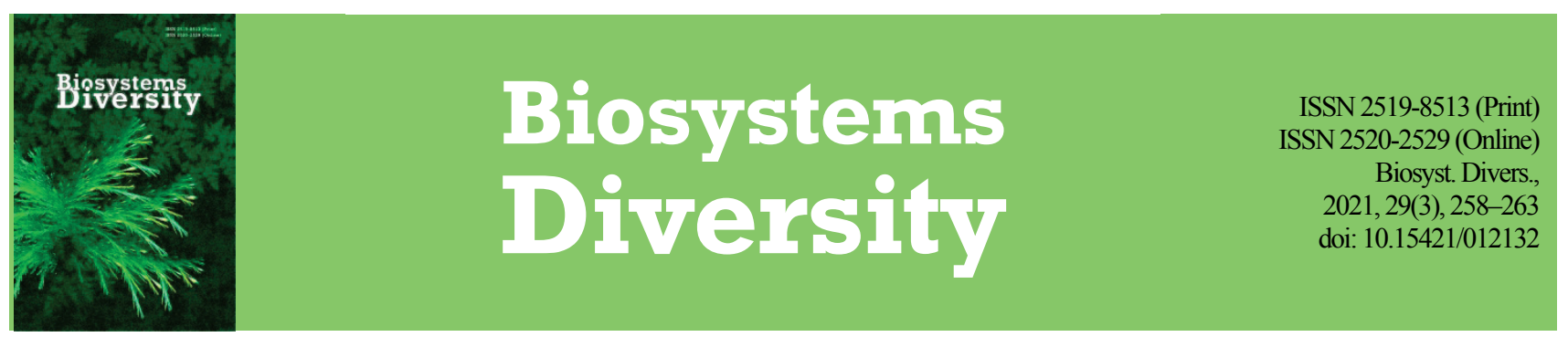

\title{
Ecology of zoophilic flies in livestock biocenoses of Ukraine
}

\author{
A. P. Paliy*, A. N. Mashkey*, L. I. Faly**, O. S. Kysterna***, H. I. Rebenko***, A. P. Palii**** \\ *Institute of Experimental and Clinical Veterinary Medicine, Kharkiv, Ukraine \\ **Oles Honchar Dnipro National University, Dnipro, Ukraine \\ ***Sumy National Agrarian University, Sumy, Ukraine \\ ****Kharkiv Petro Vasylenko National Technical University of Agriculture, Kharkiv, Ukraine
}

\author{
Article info \\ Received 14.08.2021 \\ Received in revised form 11.09 .2021 \\ Accepted 12.09.2021 \\ Institute of Experimental and Clinical \\ Veterinary Medicine, Pushkinska st., \\ 83, Kharkiv, 61023, Ukraine. \\ Tel.: + 38-066-225-34-34. \\ E-mail:paliy.dok@gmail.com \\ Oles Honchar Dnipro National \\ University, Gagarin ave., 72, \\ Dnipro, 49010, Ukraine. Tel.: +38- \\ 066-600-70-92.E-mail:faly@ua.fm \\ Sumy National Agrarian University \\ Gerasim Kondratiev st., 160, \\ Sumy, 40021, Ukraine. \\ Tel.: +38-095-889-54-65. E-mail: \\ rebenko.halina@gmail.com \\ Kharkiv Petro Vasylenko National \\ Technical University of Agriculture, \\ Alchevskyh st., 44, Kharkiv, 61002, \\ Ukraine. Tel.: +38-063-712-82-42. \\ E-mail:paliv.andri\}@ukr.net
}

\section{Introduction}

Zoophilic flies are an ecologically plastic insect group adapted to the most diverse conditions of existence. The main criterion of designating this group was that larvae and imagoes of flies have ecological (trophic, topical, phoric) relationships with farm livestock and their vital products in the conditions of their indoor and pasture maintenance. Synanthropic fly species have biotic relationships with humans and their buildings, and consume the remains of organic products for their feeding and development. It is not easy to distinguish between synanthropic and zoophilic species since the existence of farm livestock is determined by human activity (Veselkin, 1989; Malik et al., 2007).

Flies cause significant economic damage. Hematophages that may reduce the indicators of the animal industry are of particular importance. Synanthropic fly species are involved in the mechanical transmission of various pathogens, mainly bacteria (Soto et al., 2014; Khamesipour et al., 2018). Larvae of some species can develop under the skin of animals and cause the development of severe myiasis. The role of insects, including flies, as carriers of parasitic diseases is also important (Boyko et al., 2009; Makaida et al., 2021). Musca domestica Linnaeus, 1758 is actively involved in the transmission of exogenous forms of ascaridates and esophagostomes. Musca autumnalis De Geer, 1776 may act as the source of trichostrongylate distribution. Muscina stabulans (Fallén, 1817) and Stomoxys calcitrans (Linnaeus, 1758) are known to be mechanical carriers of Ancylostoma caninum (Ercolani, 1859) larvae and Trichuris vulpis (Frölich, 1789) eggs respectively (Paliy et al., 2018; Kababian et al., 2020). The species diversity and the number of zoophilic flies vary depending on the type and age of potential hosts (vertebrates). The fly species specificity to certain types of warm-blooded animals is poorly expressed. Many researchers note that the greatest faunal composition of flies is observed on livestock farms for the maintenance and breeding of cattle and pigs (Skovgård et al., 2012; Tummeleht et al., 2020). Imagoes of zoophilic flies are blood-sucking, or they feed on secretions from the mucous membranes, lacrimal and sweat glands of vertebrates. In livestock complexes, new ecological niches for these Diptera can develop. Zoophilic flies have different behaviour when parasitizing on farm animals. It is known that Haematobosca stimulans (Meigen, 1824) and S. calcitrans choose places for bloodsucking on the back, sides of the abdomen, and legs of animals. Haematobia irritans (Linnaeus, 1758) usually parasitizes on the back, legs, and udder nipples of animals, and M. autumnalis is recorded most often on the head of animals (Salem et al., 2012; Semelbauer et al., 2018).

Muscidae is the dominant part of the zoophilic fly complex in terms of the species number. The species of this family are broadly distributed in all zoogeographic regions (Muenworn et al., 2010; Ola-Fadunsin et al., 2020). Muscidae larvae live in various environments: decomposing plant remains, manure, compost, animal corpses, fungal fruit bodies, moss, silt, living tissues of plants and animals, etc. Most often, the larvae of muscid flies are facultative saprophages, or facultative, obligate predators. The larvae of some species act as ectoparasites or endoparasites that feed on blood or cause miasis (Lendzele et al., 2019). The type of muscids' imaginal nutrition is determined by the morphological features of their proboscis structure. Facultative hematophages and polyphages of $\mathrm{Musca}$ genus (including $M$. domestica) are characterized by loosening-filteringsucking type of the oral disk with developed prestomal teeth and lamellar 
interdental plate. Flies that have this type of proboscis can damage fresh dried wounds of animals and absorb the released blood, lymph, intercellular fluid. Obligate hematophages - on the example of S. calcitrans - have a glossinoid proboscis of the rasping-sucking type (Kulikova et al., 1999; Gregor et al., 2016). The reproductive strategy of muscids is also diverse. Saprophage species are characterized by three larval ages (trimorphic larvae). Larvae of age II or III (dimorphic or monomorphic larvae) emerge from the eggs of predatory muscid flies (Wall et al., 2008; Mavoungou et al., 2017).

There is competition between different fly species in nature, which manifests in behavioural characteristics during their feeding and reproduction. Especially fierce competition is observed among the inhabitants of temporary organic substrates such as corpses, excrement. The tense relationships between species over the evolutionary process have promoted the formation of highly sensitive sensory organs in imago flies which allow them to find food supplies as quickly as possible. For temporary living places, significant succession is characteristic, namely change of species complexes. If the species are adapted to life at the same successional stage, then the competition between them can be especially fierce. It is known that fly larvae that live on carrion or in animal excrement secrete specific substances that prevent the development of nematodes and fungi feeding on the same substrate. In other cases, female flies avoid egglaying substrates stocked by competitive species and parasites; it was studied on the example of S. calcitrans (Baleba et al., 2020).

The objective of the study was identifying the dominant species of zoophilic flies in livestock biocenoses of forest-steppe and steppe zones of Ukraine; to study the biology and ecology features of dominant fly species in field and laboratory conditions.

\section{Materials and methods}

Zoophilic flies were caught during active flight (May-October) in the premises for keeping cattle, pigs, sheep, poultry, on the territory of manure storage facilities and pastures located in the forest-steppe and steppe zones of Ukraine (Dnipropetrovsk, Donetsk, Zhytomyr, Zaporozhye, Kirovograd, Poltava, Kharkiv, Kherson oblasts) in the period from 2000 to 2020 (Table 1).

Entomological nets and exhausts were used to catch imago flies in livestock premises, as well as special traps recommended by a number of researchers (McCravy, 2018; Marchioro et al., 2020). Fly larvae and puparia were collected manually in places of their intensive breeding (rotting substrate, manure). Field collections on pastures were carried out according to the generally accepted methods used in entomology (Fasulati, 1971; Lamarre et al., 2018). Insect imagoes were fixed in $70 \%$ ethanol solution for the further determining of the species composition. The collected fly larvae and pupae were incubated in insectariums for further laboratory cultivation. More than 9,194 imago and larvae specimens of zoophilic flies were collected during the research period. Assistance in identification of fly species was provided by I. A. Mashkey, A. A. Mish- chenko, researchers of the Institute of Experimental and Clinical Veterinary Medicine.

After emergence from the puparia, imagoes of house fly (M. domestica), face fly (M. autumnalis), and dung fly (Neomyia cornicina (Fabricius, 1781)) were selected for further laboratory cultivation. The flies were kept in cages measuring $50 \times 50 \times 50 \mathrm{~cm}$. The frame of these containers was made of stainless wire covered with a piece of mesh fabric with the cell diameter of 1-2 $\mathrm{mm}$. On the bottom of the cages, we placed dishes with a nutrient medium, water, and the substrate for laying eggs. A mixture of powdered milk with glucose (2:1) was used as the food for $M$. domestica and $N$. cornicina imagoes. The daily consumption per specimen was 5 $10 \mathrm{mg}$ of the mixture. To feed M. autumnalis, we used multicomponent nutrient medium consisting of milk powder, glucose, and stabilized bovine blood. Water was supplied as a moistened cotton swab in cups. Wheat bran steamed in hot water (1:2) was used for egg laying by M. domestica. The substrate for eggs of N. cornicina, M. autumnalis was fresh cattle feces ( $450-600 \mathrm{~g}$ in a cage at the rate of $1.5-2.5 \mathrm{~g}$ per larva). $300-500$ imagoes of the same species were kept per one cage. In the boxes for insect cultivation, the temperature was maintained at $25-28^{\circ} \mathrm{C}$ with $55-65 \%$ relative humidity and photoperiod of 16 hours. To quantify the laid eggs, the egg rafts of flies were placed in a $10 \mathrm{~cm}^{3}$ vessel that was filled with water. The upper layer of water was drained, and the settled eggs were counted (about 5000 eggs per $1 \mathrm{~cm}^{3}$ ). Then water was added up to the mark of $5 \mathrm{~cm}^{3}$, and the resulting suspension was shaken and, without letting it settle, $1 \mathrm{~cm}^{3}$ (about 1000 eggs) was collected. Then, the fly eggs were placed in $0.5 \mathrm{~L}$ containers with a cultivation medium.

For the experiments on the intraspecific competition of three cultivated Muscidae species in the conditions of nutrient substrate deficiency, we used 300 and $500 \mathrm{~cm}^{3}$ containers. The species were kept separately. Samples of cattle feces $(25,50,100 \mathrm{~g})$ were added to the cages and 50 first-age larvae were placed in each. We used two fly species in each of the experiment on interspecific competition in the conditions of nutrient substrate deficiency. In the first experiment, M. autumnalis and N. cornicina were used, and M. domestica and M. autumnalis in the second. We used $500 \mathrm{~cm}^{3}$ containers with weighed amounts of feces equaling 25 , $50,100 \mathrm{~g}$. A total of 50 first-age larvae of two fly species were placed in each cage with a certain amount of cow feces.

\section{Results}

Twenty seven species of zoophilic flies were identified in the specialized livestock complexes for cattle, pigs, sheep, poultry located in the territory of eight regions of Ukraine (Table 1). Among them, Muscidae, Calliphoridae, Fanniidae, and Sarcophagidae accounted for $74.1 \%$, $14.8 \%, 7.4 \%$, and $3.7 \%$, respectively. The largest number of zoophilic fly species was recorded in the premises for cattle keeping. The lowest number of parasitic Diptera species was recorded in poultry farming premises. $M$. domestica and S. calcitrans were identified in all livestock and poultry complexes (Table 2).

Table 1

Coordinates of the research area and the sampling calendar (livestock biocenoses in forest-steppe and steppe Ukraine)

\begin{tabular}{|c|c|c|c|c|c|}
\hline \multirow{2}{*}{ Sampling area } & \multicolumn{2}{|c|}{ Date } & \multicolumn{3}{|c|}{ Number of samples, pcs. } \\
\hline & Year & Month & Premise type & Spike camp & Pasture \\
\hline \multirow{3}{*}{$\begin{array}{l}\text { Dnipropetrovsk oblast, Verkhnedniprovsky district, Dniprovsky urban-type settlement } \\
48^{\circ} 35^{\prime} 40^{\prime \prime} \mathrm{N} 34^{\circ} 25^{\prime} 11^{\prime \prime} \mathrm{E}\end{array}$} & 2009 & June & 20 & 20 & - \\
\hline & 2010 & June & 20 & 20 & - \\
\hline & 2011 & September & 20 & 20 & - \\
\hline Donetsk oblast, Slavyansky district, Alexandrovka village & 2005 & June & 20 & - & - \\
\hline $48^{\circ} 49^{\prime} 11^{\prime \prime} \mathrm{N} 37^{\circ} 24^{\prime} 7^{\prime \prime} \mathrm{E}$ & 2006 & June & 20 & - & - \\
\hline Donetsk oblast, Slavyansky district, Dmitrovka village & 2007 & July & 20 & - & - \\
\hline $48^{\circ} 45^{\prime} 15^{\prime \prime} \mathrm{N} 37^{\circ} 22^{\prime} 55^{\prime \prime} \mathrm{E}$ & 2008 & July & 20 & - & - \\
\hline Zhytomyr oblast, Popelnyansky district, Makarovka village & 2007 & June & 20 & - & - \\
\hline $49^{\circ} 59^{\prime} 51^{\prime \prime} \mathrm{N} 29^{\circ} 322^{\prime \prime} 4^{\prime \prime} \mathrm{E}$ & 2006 & June & 20 & - & - \\
\hline Zhytomyr oblast, Popelnyansky district, Novoselitsa village & 2007 & June & 20 & 20 & - \\
\hline $49^{\circ} 54^{\prime} 10^{\prime \prime} \mathrm{N} 29^{\circ} 37^{\prime} 37^{\prime \prime} \mathrm{E}$ & 2006 & June & 20 & 20 & - \\
\hline Zhytomyr oblast, Popelnyansky district, Erchik village & 2007 & June & 20 & - & - \\
\hline $49^{\circ} 59^{\prime} 46^{\prime \prime} \mathrm{N} 29^{\circ} 34^{\prime} 45^{\prime \prime} \mathrm{E}$ & 2006 & June & 20 & - & - \\
\hline Zhytomyr oblast, Popelnyansky district, Sokolcha village & 2007 & June & 20 & - & - \\
\hline $49^{\circ} 59^{\prime} 16^{\prime \prime} \mathrm{N} 29^{\circ} 19^{\prime} 0^{\prime \prime} \mathrm{E}$ & 2006 & June & 20 & - & - \\
\hline Zhytomyr oblast, Baranovsky district, Ostrozhok village & 2011 & July & - & - & 20 \\
\hline $50^{\circ} 23^{\prime} 44^{\prime \prime} \mathrm{N} 27^{\circ} 44 ' 22^{\prime \prime} \mathrm{E}$ & 2013 & July & - & - & 20 \\
\hline
\end{tabular}




\begin{tabular}{|c|c|c|c|c|c|}
\hline \multirow{2}{*}{ Sampling area } & \multicolumn{2}{|c|}{ Date } & \multicolumn{3}{|c|}{ Number of samples, pcs. } \\
\hline & Year & Month & Premise type & Spike camp & Pasture \\
\hline & 2020 & August & - & - & 20 \\
\hline Zhytomyr oblast, Baranovsky district, Rogachev village & 2011 & July & 20 & - & - \\
\hline $50^{\circ} 24^{\prime} 34^{\prime \prime} \mathrm{N} 27^{\circ} 43 \prime 26^{\prime \prime} \mathrm{E}$ & 2013 & July & 20 & - & - \\
\hline Zaporozhye oblast, Melitopol district, Konstantinovka village & 2004 & June & 10 & - & 10 \\
\hline \multirow[t]{2}{*}{$46^{\circ} 49^{\prime} 32^{\prime \prime} \mathrm{N} 35^{\circ} 25^{\prime} 32^{\prime \prime} \mathrm{E}$} & 2006 & July & 20 & - & - \\
\hline & 2001 & June & 20 & 20 & - \\
\hline Kirovograd oblast, Petrovsky district, Luganka village & 2002 & June & 20 & 20 & - \\
\hline \multirow[t]{3}{*}{$48^{\circ} 1124^{\prime \prime} \mathrm{N} 33^{\circ} 17^{\prime} 8^{\prime \prime} \mathrm{E}$} & 2003 & August & 20 & 20 & - \\
\hline & 2004 & September & 20 & 20 & - \\
\hline & 2001 & June & 20 & 20 & - \\
\hline Kirovograd oblast, Petrovsky district, Petrovo urban-type settlement & 2002 & June & 20 & 20 & - \\
\hline \multirow{2}{*}{$48^{\circ} 20^{\prime} 5^{\prime \prime} \mathrm{N} 33^{\circ} 16^{\prime} 13^{\prime \prime} \mathrm{E}$} & 2003 & August & 20 & 20 & - \\
\hline & 2004 & September & 20 & 20 & - \\
\hline \multirow{3}{*}{$\begin{array}{l}\text { Poltava oblast, Novosanzharsky district, Kuntsevo village } \\
49^{\circ} 22^{\prime} 47^{\prime \prime} \mathrm{N} 34^{\circ} 22^{\prime} 25^{\prime \prime} \mathrm{E}\end{array}$} & 2000 & June & 20 & 20 & 20 \\
\hline & 2005 & July & 20 & 20 & 20 \\
\hline & 2011 & September & 20 & - & - \\
\hline \multirow{3}{*}{$\begin{array}{l}\text { Poltava oblast, Novosanzharsky district, Novi Sanzhary urban-type settlement } \\
49^{\circ} 20^{\prime} 29^{\prime \prime} \text { N } 34^{\circ} 18^{\prime} 46^{\prime \prime} \text { E }\end{array}$} & 2000 & June & 20 & 20 & 20 \\
\hline & 2011 & June & 20 & 20 & 20 \\
\hline & 2013 & August & 20 & 20 & 20 \\
\hline & 2000 & June & 20 & 20 & 20 \\
\hline Poltava oblast, Kotelevsky district, Kotelva village & 2004 & May & 20 & 20 & 20 \\
\hline \multirow[t]{2}{*}{$50^{\circ} 4^{\prime} 7^{\prime \prime} \mathrm{N} 34^{\circ} 45^{\prime} 52^{\prime \prime} \mathrm{E}$} & 2012 & July & 15 & 15 & - \\
\hline & 2014 & September & 20 & 20 & - \\
\hline \multirow{3}{*}{$\begin{array}{l}\text { Poltava oblast, Gadyatsky district, Veprik village } \\
50^{\circ} 22^{\prime} 10^{\prime \prime} \mathrm{N} 34^{\circ} 10^{\prime} 35^{\prime \prime} \mathrm{E}\end{array}$} & 2012 & June & 20 & - & - \\
\hline & 2013 & July & 20 & - & - \\
\hline & 2015 & August & 10 & - & - \\
\hline \multirow{4}{*}{$\begin{array}{l}\text { Kharkiv oblast, Zmiev district, Zadonetsky village } \\
49^{\circ} 38^{\prime} 44^{\prime \prime} \mathrm{N} 36^{\circ} 21^{\prime} 35^{\prime \prime} \mathrm{E}\end{array}$} & 2001 & May & - & - & 20 \\
\hline & 2002 & June & - & - & 20 \\
\hline & 2003 & July & - & - & 20 \\
\hline & 2010 & June & - & - & 20 \\
\hline \multirow{7}{*}{$\begin{array}{l}\text { Kharkiv oblast, Dergachev district, Malaya Danilovka village } \\
50^{\circ} 4^{\prime} 19^{\prime \prime} \mathrm{N} 36^{\circ} 9^{\prime} 46^{\prime \prime} \mathrm{E}\end{array}$} & 2004 & May & - & - & 20 \\
\hline & 2006 & July & - & - & 20 \\
\hline & 2008 & June & - & - & 20 \\
\hline & 2009 & August & - & - & 20 \\
\hline & 2010 & July & - & - & 20 \\
\hline & 2019 & July & - & - & 20 \\
\hline & 2020 & August & - & - & 20 \\
\hline \multirow{7}{*}{$\begin{array}{l}\text { Kharkiv oblast, Kharkiv district, Temnovka village } \\
49^{\circ} 47^{\prime} 47^{\prime \prime} \mathrm{N} 36^{\circ} 20^{\prime} 29^{\prime \prime} \mathrm{E}\end{array}$} & 2006 & May & - & - & 20 \\
\hline & 2007 & June & - & - & 20 \\
\hline & 2008 & June & - & - & 20 \\
\hline & 2009 & August & - & - & 20 \\
\hline & 2010 & June & - & - & 20 \\
\hline & 2016 & August & - & - & 20 \\
\hline & 2018 & June & - & - & 15 \\
\hline Kharkiv oblast, Krasnograd district, Martynovka village & 2010 & July & 20 & 20 & - \\
\hline $49^{\circ} 18^{\prime} 58^{\prime \prime} \mathrm{N} 35^{\circ} 24^{\prime} 59^{\prime \prime} \mathrm{E}$ & 2015 & June & 20 & 20 & - \\
\hline Kharkiv oblast, Novovodolazhsky district, Sosnovka village & 2011 & June & 20 & - & - \\
\hline $49^{\circ} 25^{\prime 2} 24^{\prime \prime} \mathrm{N} 35^{\circ} 39^{\prime} 20^{\prime \prime} \mathrm{E}$ & 2012 & August & 20 & - & - \\
\hline \multirow{3}{*}{$\begin{array}{l}\text { Kharkiv oblast, Zmiev district, Pervomayskoye village } \\
49^{\circ} 29^{\prime} 11^{\prime \prime} \text { N } 36^{\circ} 19^{\prime} 32^{\prime \prime} \mathrm{E}\end{array}$} & 2008 & June & 20 & 20 & - \\
\hline & 2009 & June & 20 & 20 & - \\
\hline & 2017 & June & 10 & 10 & - \\
\hline Kherson oblast, Kakhovsky district, Tavrichanka village & 2012 & July & 20 & 20 & - \\
\hline $46^{\circ} 33^{\prime} 10^{\prime \prime} \mathrm{N} 33^{\circ} 49^{\prime} 24^{\prime \prime} \mathrm{E}$ & 2013 & July & 20 & 20 & - \\
\hline
\end{tabular}

Table 2

Zoophilic fly species composition in livestock biocenoses of forest-steppe and steppe zones of Ukraine

\begin{tabular}{|c|c|c|c|c|c|}
\hline \multirow{2}{*}{ Family name } & \multirow{2}{*}{ Species name } & \multicolumn{4}{|c|}{ Animal husbandry premises for housing of: } \\
\hline & & cattle & pigs & sheep & domestic fowl \\
\hline \multirow{2}{*}{ Fanniidae } & Fannia canicularis (Linnaeus, 1761) & + & + & - & ++ \\
\hline & F. scalaris (Fabricius, 1794) & + & + & - & + \\
\hline \multirow{13}{*}{ Muscidae } & Haematobia irritans (Linnaeus, 1758) & + & - & - & - \\
\hline & H. titillans (Bezzi, 1907) & + & - & - & - \\
\hline & Haematobosca atripalpis (Bezzi, 1895) & + & - & - & - \\
\hline & H. stimulans (Meigen, 1824) & + & - & - & - \\
\hline & Hydrotaea dentipes (Fabricius, 1805) & + & - & - & - \\
\hline & Mesembrina meridiana (Linnaeus, 1758) & + & + & + & - \\
\hline & Morellia hortorum (Fallén, 1817) & + & - & - & - \\
\hline & M. simplex (Loew, 1857) & + & - & - & - \\
\hline & Musca amita Hennig, 1964 & + & - & - & - \\
\hline & M. autumnalis De Geer,1776 & + & - & - & - \\
\hline & M. domestica Linnaeus, 1758 & $+1+$ & $+1+$ & $+1+$ & $+1+$ \\
\hline & M. larvipara Porchinskiy, 1910 & + & - & - & - \\
\hline & M. osiris Wiedemann, 1830 & + & - & - & - \\
\hline
\end{tabular}




\begin{tabular}{|c|c|c|c|c|c|}
\hline \multirow{9}{*}{ Family name } & \multirow{2}{*}{ Species name } & \multicolumn{4}{|c|}{ Animal husbandry premises for housing of: } \\
\hline & & cattle & pigs & sheep & domestic fowl \\
\hline & M. tempestiva Fallén, 1817 & + & - & - & - \\
\hline & M. vitripennis Meigen, 1826 & + & - & - & - \\
\hline & Muscina levida (Harris, 1780) & + & + & - & - \\
\hline & M. stabulans (Fallén, 1817) & + & + & + & + \\
\hline & Neomyia cornicina (Fabricius, 1781) & - & - & - & - \\
\hline & $N$. viridescens (Robineau-Desvoidy, 1830) & - & - & - & - \\
\hline & Stomoxys calcitrans (Linnaeus, 1758) & $+1+$ & + & + & + \\
\hline \multirow{4}{*}{ Calliphoridae } & Calliphora vicina Robineau-Desvoidy, 1830 & + & - & ++ & - \\
\hline & Lucilia sericata (Meigen, 1826) & + & - & + & - \\
\hline & L. caesar (Linnaeus, 1758) & + & - & - & - \\
\hline & Protophormia terraenovae (Robineau-Desvoidy, 1830) & + & + & + & - \\
\hline Sarcophagidae & Wohlfahrtia magnifica (Schiner, 1862) & + & - & ++ & - \\
\hline
\end{tabular}

Note: "+1+"-high abundance of individuals of the species, "++" - mean abundance of individuals of the species, "+"- low abundance of individuals of the species, "-“- the species is absent.

The study revealed that the female $N$. cornicina lays 30-47 eggs per raft, assembled by a special secretion into 1-2 groups comprising 15-30 specimens. The dung fly looks for a recess in the thickness of the cowpat and lays eggs at $1.5-2.5 \mathrm{~cm}$ depth from the surface of the substrate. Egg laying was observed once every two days. Females lay eggs throughout their life. The eggs are white or yellowish-white, elongated in shape, slightly narrowed towards one end. On the dorsal side, the eggs are convex; on the ventral side are straight or concave with two ribs. The length of the eggs is $1.9-2.0 \mathrm{~mm}$, the width in the center equals $0.15-0.16 \mathrm{~mm}$. After the larva emerges, the rupture line on the shell of the nucleus passes from the expanded to the narrowed end. First-age larvae were colourless, with $2.7-3.4 \mathrm{~mm}$ body length and $0.6-0.8 \mathrm{~mm}$ width in the center of the body, they emerge from the eggs after 10-12 hours. After 35-46 hours, the individuals molt and enter the second larval stage. The length of the second-age larva is $3.8-5.9 \mathrm{~mm}$, the width equals $1.9-2.2 \mathrm{~mm}$. After 24 28 hours, third-age larvae emerge, becoming grey-blue or grey-green colour. The length of individuals of the third larval stage is $10.0-13.5 \mathrm{~mm}$, the width is $2.1-3.2 \mathrm{~mm}$. The prepupa is grey-blue in colour, pupation lasts for 4-6 hours. The pupae were red-brown, 5.6-8.1 mm long, and 2.5-3.2 mm wide. The dung fly development from egg to pupa lasts 90 120 hours, the pupal phase lasts $120-170$ hours, and the duration of the entire preimaginal period is 220-290 hours. The emergence of an imago fly from the pupa lasts up to 3 hours. After the emergence, imagoes are light grey, and gradually turn into blue-green as the cuticle dries. The sex ratio (males : females) in $N$. cornicina was approximately $1: 1$. The beginning of mass mating of individuals in the cage was observed 100-130 hours after emergence. The life expectancy of females in an insectarium is 80-92 days, males are less viable.

It was determined that the majority of flies in the conditions of pastures and cow sheds attack the animals in the period from early May to late September. At the same time, $M$. domestica parasitizes in livestock premises throughout the year. During the intensive flight of insects (JuneJuly), the number of domestic fly imagoes simultaneously attacking one animal reached $500-600$ or more individuals. Visual observations of behaviour of $M$. domestica in livestock premises showed significant daytime flight activity, intense attack on livestock, and the maximum accumulation of flies in the sunlit areas of the premises. During the movement of cattle to special sheds, imago houseflies migrate together with the animals. Observations of the behaviour of $M$. domestica in the preventoriums at heifer breeding farms have shown that the main food for insects is the liquid feces of calves suffering from diarrhea. A significant number of flies (up to 100 individuals) accumulated on sick animals contaminated with feces, but when the calves were given milk, flies actively flew to the drinkers.

The number of $M$. autumnalis imagoes during the intense flight was quite high. One animal could be attacked by $80-100$ individuals at one time. Face flies were observed to attack cattle in the first half of the day. In the morning, before the animals were driven off to pastures, no flight was observed, during this period the flies were in shelters (forests, shrub, and herbaceous layers). The flight activity of $M$. autumnalis was recorded only in the presence of cattle on pastures.

The seasonal dynamics of the number of $S$. calcitrans was characterized by two peaks. The first one was recorded in late June - early July. In hot days (air temperature above $25^{\circ} \mathrm{C}$ ), 30 to 50 imagoes of stable fly were seen on one animal. The second peak with a higher number of
S. calcitrans (50-100 individuals per animal) was observed in September. Crushed rotting vegetation scattered near feeders, fences, paddocks, and other places of cattle accumulation is the optimal breeding ground for the mass development of the preimaginal phases of stable fly. During the survey of such sites, $100 \%$ level of infestation with this species was recorded. Observations of the behaviour of $S$. calcitrans on dairy farms revealed that the flies spend night under the canopies of the sheds, and in the morning the females look for places to lay eggs (rotting plants, liquid manure, old silage pits). Mass attacks on cattle were recorded during afternoon milk yield. In the afternoon and evening hours, the flies were low-active. In winter, no breeding sites of $S$. calcitrans were found in livestock premises. In December and January, number of imagoes in the premises was low. The fly index was $1-3$ specimens per animal. Since this species prefers manure mixed with vegetation for laying eggs, it is possible that individuals of the autumn generation are active in winter.

The study revealed that under conditions of intraspecific competition, the species of the Musca genus were characterized by high degree of survival in conditions of critical nutritional deficiency and increased density of individuals ( 50 larvae per $25 \mathrm{~g}$ of nutrient medium with an insectarium volume of $300 \mathrm{~cm}^{3}$ ). The low level of emergence of $N$. cornicina imagoes $(14.6 \%)$ indicates that the larvae do not accumulate enough nutrients for their metamorphosis (Table 3 ).

\section{Table 3}

Survival of fly larvae in conditions of intraspecific competition with a deficiency of nutrient substrate (50 larvae, $x \pm S D, n=3$ )

\begin{tabular}{|c|c|c|c|c|c|}
\hline $\begin{array}{l}\text { Volume } \\
\text { of the insecta- } \\
\text { rium, } \mathrm{cm}^{3}\end{array}$ & $\begin{array}{l}\text { Weight } \\
\text { of feces, } g\end{array}$ & $\begin{array}{l}\text { Species } \\
\text { name }\end{array}$ & $\begin{array}{c}\text { Pupated } \\
\text { larvae, ind. }\end{array}$ & $\begin{array}{c}\text { Imago } \\
\text { emerged, } \\
\text { ind. }\end{array}$ & $\begin{array}{c}\text { Survival rate } \\
\text { of individuals, } \\
\%\end{array}$ \\
\hline \multirow{3}{*}{300} & \multirow{3}{*}{25} & M. domestica & $22.3 \pm 2.1$ & $19.3 \pm 3.1$ & 38.6 \\
\hline & & M. autumnalis & $21.0 \pm 2.0$ & $17.0 \pm 3.6$ & 34.0 \\
\hline & & N. cornicina & $11.6 \pm 0.6$ & $7.3 \pm 2.1$ & 14.6 \\
\hline \multirow{3}{*}{500} & \multirow{3}{*}{50} & M. domestica & $39.3 \pm 3.2$ & $32.0 \pm 3.6$ & 64.0 \\
\hline & & M. autumnalis & $31.0 \pm 2.0$ & $19.6 \pm 3.2$ & 39.2 \\
\hline & & N. cornicina & $28.3 \pm 2.1$ & $12.0 \pm 2.6$ & 24.0 \\
\hline \multirow{3}{*}{500} & \multirow{3}{*}{100} & M. domestica & $49.3 \pm 3.1$ & $48.3 \pm 5.9$ & 96.6 \\
\hline & & M. autumnalis & $46.0 \pm 4.0$ & $45.6 \pm 6.4$ & 91.2 \\
\hline & & N. cornicina & $37.3 \pm 4.2$ & $36.3 \pm 4.5$ & 72.6 \\
\hline
\end{tabular}

After a two-fold increase in the volume of the insectarium and the nutrient substrate, having constant number of fly larvae, a significant increase in the viability of individuals of all species studied in the laboratory was observed. When the ratio of the amount of nutrient medium equaled $1 \mathrm{~g}$ per larva, the emergence of $M$. domestica, $M$. autumnalis, $N$. cornicina imagoes increased by $25.4 \%, 5.2 \%, 9.4 \%$. After even greater increase in the amount of nutrient medium ( $2 \mathrm{~g}$ per larva), the maximum imago emergence of all the studied fly species was recorded. It is possible that for species in Musca genus (M. domestica, M. autumnalis), this volume of nutrient substrate is optimal, and the emergence of adults is close to $100 \%$ (Table 3).

The results of the studies reveal the relationship between nutrient medium volume and pupated larvae percentage and emerged $N$. cornicina and $M$. autumnalis imagoes. When the ratio of fecal mass was $0.5 \mathrm{~g}$ per larva, the emergence of imagoes of the cultivated species was low. After increasing the weight of feces to the ratio of $1 \mathrm{~g}$ per larva, the emergence 
of adults from puparia increased: $N$. cornicina by $24.0 \%$, M. autumnalis by $28.6 \%$. In the optimal conditions of maintenance ( $2 \mathrm{~g}$ of feces per larva), there was uneven increase in the number of imagoes that emerged between the two species. In the conditions of interspecific competition, $M$. autumnalis suppressed $N$. cornicina. This was especially evident in the presence of sufficient amount of nutrient substrate ( $100 \mathrm{~g}$ of feces). Thus, emergence of M. autumnalis imagoes was close to $100 \%$, and the emergence of $N$. cornicina adult individuals was two times lower (Table 4). When dung flies were cultivated in monoculture, the indicators of imagoes emerging from puparia (in similar keeping conditions) were almost 1.5 times higher (Table 3 ).

\section{Table 4}

Survival of fly larvae in conditions of interspecific competition in the conditions of shortage of nutrient substrate (50 larvae, capacity $500 \mathrm{~cm}^{3}, x \pm S D, n=3$ )

\begin{tabular}{clrcc}
\hline $\begin{array}{c}\text { Wright } \\
\text { of feces, g }\end{array}$ & Species name & $\begin{array}{c}\text { Pupated } \\
\text { larvae, ind. }\end{array}$ & $\begin{array}{c}\text { Imago } \\
\text { emerged, ind. }\end{array}$ & $\begin{array}{c}\text { Survival rate } \\
\text { of individuals, \% }\end{array}$ \\
\hline \multirow{2}{*}{25} & N. cornicina & $8.3 \pm 2.5$ & $3.0 \pm 1.0$ & 6.0 \\
& M. autumnalis & $13.3 \pm 3.1$ & $7.3 \pm 1.5$ & 14.6 \\
50 & N. cornicina & $18.0 \pm 2.0$ & $15.0 \pm 3.6$ & 30.0 \\
& M. autumnalis & $23.6 \pm 3.2$ & $21.6 \pm 4.0$ & 43.2 \\
\multirow{2}{*}{100} & N. cornicina & $29.3 \pm 3.5$ & $25.3 \pm 5.6$ & 50.6 \\
& M. autumnalis & $49.3 \pm 5.0$ & $48.3 \pm 5.1$ & 96.6 \\
\multirow{2}{*}{50} & M. domestica & $29.3 \pm 3.0$ & $28.0 \pm 4.6$ & 56.0 \\
& M. autumnalis & $13.0 \pm 3.0$ & $7.3 \pm 2.5$ & 14.6 \\
\multirow{2}{*}{100} & M. domestica & $42.6 \pm 4.2$ & $41.3 \pm 4.2$ & 82.6 \\
& M. autumnalis & $23.3 \pm 3.8$ & $21.0 \pm 4.6$ & 42.0 \\
& M. domestica & $49.0 \pm 6.2$ & $48.6 \pm 4.2$ & 97.2 \\
& M. autumnalis & $45.3 \pm 4.0$ & $43.0 \pm 4.0$ & 86.0 \\
\hline
\end{tabular}

During the interspecific competition between $M$. domestica and M. autumnalis, the house fly took the leading position. A high percentage of both the emerging pupae and imagoes of this species was recorded: more than half of the individuals participating in the experiment, even with a maximum nutritional deficiency ( $25 \mathrm{~g}$ feces weight). In similar conditions, the emergence of adult $M$. autumnalis was three times lower. Increase in the amount of nutrient substrate increased the survival rate of individuals of both species. The presence of nutrient medium in insectariums in the amount of $50 \mathrm{~g}$ reduced the gap between competing species; the imago emergence was 2:1 in favour of $M$. domestica. When the use of $100 \mathrm{~g}$ of feces (at the rate of $2 \mathrm{~g}$ per 1 larva), high rates of larvae pupation and imago emergence of both studied species were recorded. The gap between the species further reduced, and $M$. domestica individuals slightly dominated (Table 4).

\section{Discussion}

In biocenoses, populations of different species are in continuous interaction. Competitive relations in the process of long-term interspecific competition are an important factor regulating the abundance and composition of species in a community. Ecological niches of species often overlap, which creates conditions for interspecific competition. Competition arises if the resource is limited, and species have similar needs, for example, they use the same food and habitat for their offspring development (Kishi, 2015). In our laboratory experiments determining the competitiveness of the species, we used N. cornicina, M. domestica, and M. autumnalis which require manure as the resource for their development in preimaginal phases. Of these three fly species, in conditions of increased density of individuals and limited food for larvae, $M$. domestica had the greatest competitiveness.

As a result of the competition in the biocenosis, only species with different environmental requirements can exist together; that is, they occupy different ecological niches. Stable coexistence of closely related species always means that some specific differences in morphology of these species, development cycles, and feeding methods give them the opportunity to avoid acute competition netween themselves (Bush et al., 2008). The house fly is the most adapted species to the conditions of livestock premises. The number of M. domestica is relatively high during the year, although some fluctuations were noted in winter. The density index of house fly does not fall below 30 individuals per animal (December, Janu- ary). Perhaps this is due to the fact that hidden places or flies to breed in livestock premises remain even if all sanitation standard operating procedures for removing manure were followed. Due to decrease in the number of animals grazed on pastures and the high density of house fly in summer camps and livestock facilities, decrease in the number of $M$. autumnalis was currently observed. Density index of face fly in summer camps accounted for 3-5 individuals, and 2-4 individuals per animal in the premises. This species is inferior in competitive relations to $M$. domestica, as confirmed by our research.

Human economic activity is the main source of biosphere contamination. The increasing introduction of toxic substances into the environment negatively affects living organisms (Shulman et al., 2017; Lieshchova et al., 2018). Modern farming methods exclude the use of chemical toxic insecticides in animal husbandry. Therefore, the development of new environmentally safe methods to control parasitic Diptera is a promising direction. Among the effective alternative control methods, the use of bioinsecticides is highlighted. The use of extracts from various plants prevents the natural development of the pre-imago phases of flies and negatively affects their reproductive potential. The use of various traps significantly reduces the number of flies during the grazing season (Kienitz et al., 2018; Nisar et al., 2021). The organization of an effective control of zoophilic flies can be carried out only with the strict compliance with the sanitary and hygienic standards in the territories of livestock complexes (Malik et al., 2007; Paliy et al., 2018).

\section{Conclusion}

In the territory of livestock biocenoses in the forest-steppe and steppe zones of Ukraine, there were found 27 species of zoophilic flies, among which the species of the Muscidae family dominated (74.1\%). The largest number of parasitic Diptera species was recorded in livestock facilities for keeping cattle. The lowest number of species was recorded in poultry farming premises. M. domestica and $S$. calcitrans were recorded in all livestock and poultry farms.

In the laboratory conditions, we found that the development of $N$. cornicina from egg to pupa lasted 90-120 hours. The duration of the entire preimaginal period was 220-290 hours. The beginning of mass mating was 100-130 hours after emergence. The life expectancy of females in the insectarium was 80-92 days.

The study revealed that during the intense flight period (June-July), the number of $M$. domestica imagoes simultaneously attacking one animal was 500-600 individuals. We should note that M. autumnalis imagoes attacked cattle only in the first half of the day. One animal can be attacked simultaneously by $80-100$ individuals. The seasonal dynamics of $S$. calcitrans abundance were characterized by two peaks. The first one was in late June - early July (30-50 individuals per animal). The second one occurred in September (50-100 individuals per animal). Mass attacks of $S$. calcitrans on cattle were observed at lunchtime. In the evening hours, the flies were low-active.

As for the competitiveness of the three fly species, the study revealed that the species in Musca genus were characterized by high-degree survival in the conditions of intraspecific competition during critical shortage of a nutrient substrate ( $0.5 \mathrm{~g}$ of feces per larva) and increased density of individuals. For $N$. cornicina imagoes, very low emergence was recorded $(14.6 \%)$. After 2-fold increase in the volume of insectarium and weight of feces (1 g per larva), the emergence of M. domestica, M. autumnalis and $N$. cornicina imago increased by $25.4 \%, 5.2 \%$, and $9.4 \%$, respectively. We observed the highest rate of emergence of imagoes of all the studied fly species with increase in the amount of nutrient medium to $2 \mathrm{~g}$ per larva.

The study revealed that M. autumnalis suppressed N. cornicina in the conditions of interspecific competition. If there was sufficient amount of nutrient substrate (100 g weight of feces), the adult M. autumnalis emergence was $96.6 \%$, and N. cornicina emergence was twice lower. During the cultivation of $N$. cornicina in the monoculture in identical maintenance conditions, the emergence of imagoes was almost 1.5 times higher. The house fly dominated in the conditions of interspecific competition of M. domestica and M. autumnalis. Even with critical shortage of nutritional resource ( $25 \mathrm{~g}$ weight of feces), the imago emergence was significant 
(56.0\%). In similar conditions, the emergence of adult $M$. autumnalis was three times lower. Increase in the nutrient medium ( $50 \mathrm{~g}$ weight of feces) narrowed the gap between these competing species. With the use of $100 \mathrm{~g}$ of feces, we observed high rates of pupation of larvae and emergence of imagoes of both species. Individuals of $M$. domestica slightly dominated.

\section{References}

Baleba, S. B. S., Torto, B., Masiga, D., Getahun, M. N., \& Weldon, C. W. (2020). Stable flies, Stomoxys calcitrans L. (Diptera: Muscidae), improve offspring fitness by avoiding oviposition substrates with competitors or parasites. Frontiers in Ecology and Evolution, 8, 5.

Boyko, A., Brygadyrenko, V., Shendryk, L., \& Loza, I. (2009). Estimation of the role of antropo-zoonosis invasion agents in the counteraction to bioterrorism. Counteraction to Chemical and Biological Terrorism in East European Countries. NATO Science for Peace and Security Series A: Chemistry and Biology. Springer Nature. Pp. 309-315.

Bush, S. E., \& Malenke, J. R. (2008). Host defence mediates interspecific competition in ectoparasites. Joumal of Animal Ecology, 77(3), 558-564.

Gregor, F., Rozkošný, R., Barták, M., \& Vaňhara, J. (2016). Manual of Central European Muscidae (Diptera). Morphology, taxonomy, identification and distribution. Schweizerbart Science Publishers, Schweizerbart.

Kababian, M., Mozaffari, E., Akbarzadeh, K., Shabani Kordshouli, R., Saghafipour, A., \& Shams, S. (2020). Identification of bacteria contaminating Musca domestica (Diptera: Muscidae) collected from animal husbandries. Shiraz E-Medical Journal, 21(4), e92018.

Khamesipour, F., Lankarani, K. B., Honarvar, B., \& Kwenti, T. E. (2018). A systematic review of human pathogens carried by the housefly (Musca domestica L.). BMC Public Health, 18(1), 1049.

Kienitz, M. J., Heins, B. J., \& Moon, R. D. (2018). Evaluation of a commercial vacuum fly trap for controlling flies on organic dairy farms. Journal of Dairy Science, 101(5), 4667-4675.

Kishi, S. (2015). Reproductive interference in laboratory experiments of interspecific competition. Population Ecology, 57, 283-292.

Kulikova, N. A., Stakovetskaya, O. K., Surakova, T. V., \& Ratyn, A. I. (1999). Vnutrividovaya izmenchivost' razmerov golovy i skleritov khobotka mukh semeystva Muscidae (Diptera) [Intraspecific variability in the size of the head and sclerites of the proboscis of flies of the family Muscidae (Diptera)]. The Kharkov Entomological Society Gazette, 7(2), 5-11 (in Russian).

Lamarre, G. P. A., Juin, Y., Lapied, E., Le Gall, P., \& Nakamura, A. (2018). Using field-based entomological research to promote awareness about forest ecosystem conservation. Nature Conservation, 29(2), 39-56.

Lendzele, S. S., François, M. J., Roland, Z.-K. C., Armel, K. A., \& Duvallet, G. (2019). Factors influencing seasonal and daily dynamics of the genus Stomoxys Geoffroy, 1762 (Diptera: Muscidae), in the Adamawa Plateau, Cameroon. International Journal of Zoology, 2019, 3636943.

Lieshchova, M. A., Tishkina, N. M., Bohomaz, A. A., Gavrilin, P. M., \& Brygadyrenko, V. V. (2018). Combined effect of glyphosphate, saccharin and sodium benzoate on rats. Regulatory Mechanisms in Biosystems, 9(4), 591-597.
Makaida, M. V., Pakhomov, O. Y., \& Brygadyrenko, V. V. (2021). Effect of increased ambient temperature on seasonal generation number in Lucilia sericata (Diptera, Calliphoridae). Folia Oecologica, 48(2), 191-198.

Malik, A., Singh, N., \& Satya, S. (2007). House fly (Musca domestica): A review of control strategies for a challenging pest. Journal of Environmental Science and Health, part B, 42(4), 453-469.

Mavoungou, J. F., Nguema, R. M., Acapovi, G. L., Koumba, R. Z., Mounioko, F., Lendzele, S. S., Bakakas, I. K., Gilles, J., Duvallet, G., M'Batchi, B., \& Picard, N. (2017). Breeding sites of Stomoxys spp (Diptera: Muscidae), a preliminary study in the Makokou region (North-East Gabon). Vector Biology Journal, 2(1), 115.

McCravy, K. W. (2018). A review of sampling and monitoring methods for beneficial arthropods in agroecosystems. Insects, 9(4), 170.

Muenworn, V., Duvallet, G., Thainchum, K., Tuntakom, S., Tanasilchayakul, S., Prabaripai, A., Akratanakul, P., Sukonthabhirom, S., \& Chareonviriyaphap, T. (2010). Geographic distribution of stomoxyine flies (Diptera: Muscidae) and diurnal activity of Stomoxys calcitrans in Thailand. Journal of Medical Entomology, 47(5), 791-797.

Nisar, M. S., Ismail, M. A., Ramzan, H., Maqbool, M. M., Ahmad, T., Ghramh, H. A., Khalofah, A., Kmet, J., Horvát, M., \& Farooq, S. (2021). The impact of different plant extracts on biological parameters of house fly [Musca domestica (Diptera: Muscidae)]: Implications for management. Saudi Journal of Biological Sciences, 28(7), 3880-3885.

Paliy, A. P., Sumakova, N. V., Paliy, A. P., \& Ishchenko, K. V. (2018). Biological control of house fly. Ukrainian Journal of Ecology, 8(2), 230-234.

Salem, A., Franc, M., Jacquiet, P., Bouhsira, E., \& Liénard, E. (2012). Feeding and breeding aspects of Stomoxys calcitrans (Diptera: Muscidae) under laboratory conditions. Parasite, 19(4), 309-317.

Semelbauer, M., Mangová, B., Barta, M., \& Kozánek, M. (2018). The factors influencing seasonal dynamics and spatial distribution of stable fly Stomoxys calcitrans (Diptera, Muscidae) within stables. Insects, 9(4), 142.

Shulman, M. V., Pakhomov, O. Y., \& Brygadyrenko, V. V. (2017). Effect of lead and cadmium ions upon the pupariation and morphological changes in Calliphora vicina (Diptera, Calliphoridae). Folia Oecologica, 44(1), 28-37.

Skovgård, H., \& Nachman, G. (2012). Population dynamics of stable flies Stomoxys calcitrans (Diptera: Muscidae) at an organic dairy farm in Denmark based on mark-recapture with destructive sub-sampling. Environmental Entomology, 41(1), 20-29.

Soto, D., Fowler, F. E., Sandelin, B. A., \& Mullens, B. A. (2014). Musca autumnalis (Diptera: Muscidae) and the host-specific nematode Paraiotonchium autumnale (Tylenchida: Iotonchiidae) in Southern California. Journal of Medical Entomology, 51(1), 288-292.

Tummeleht, L., Jürison, M., Kurina, O., Kirik, H., Jeremejeva, J., \& Viltrop, A. (2020). Diversity of Diptera species in Estonian pig farms. Veterinary Sciences, $7(1), 13$.

Veselkin, G. A. (1989). Zoofil'nyye mukhi (Diptera, Cyclorrhapha) domashnikh zhivotnykh fauny SSSR [Zoophilic flies (Diptera, Cyclorrhapha) of domestic animals of the fauna of the USSR]. Zoologicheskij Institut, Leningrad (in Russian).

Wall, R., Anderson, E., \& Lee, C. M. (2008). Seasonal abundance and reproductive output of the dung flies Neomyia cornicina and N. viridescens (Diptera: Muscidae). Bulletin of Entomological Research, 98(4), 397-403. 